\title{
NOMENCLATURAL SURVEY OF THE GENUS AMARANTHUS (AMARANTHACEAE). 11. DIOECIOUS AMARANTHUS SPECIES BELONGING TO THE SECT. SAUERANTHUS
}

\author{
Duilio lamonico
}

Department of Biology, Botany Unit, University of Pisa, via Luca Ghini 13, 56126 Pisa, Italy; d.iamonico@yahoo.it (author for correspondence).

\begin{abstract}
Iamonico, D. 2020. Nomenclatural survey of the genus Amaranthus (Amaranthaceae). 11. Dioecious Amaranthus species belonging to the sect. Saueranthus. Darwiniana, nueva serie 8(2): 567-575.

A nomenclatural study of Amaranthus names, linked to the dioecious taxa belonging to the sect. Saueranthus (subgen. Acnida), was carried out. All studied names are validly published but in need of nomenclatural clarifications. Lectotypes are designated for A. greggii var. muelleri (NY), whereas for $A$. ambigens, $A$. annectens, A. arenicola, $A$. myrianthus, and $A$. watsonii holotypes were cited (deposited at US, BM, GH, and US). Isotypes where found for $A$. ambigens (one specimen at NY), A. myrianthus (five specimens at GH, M, MO, RM, and US), and A. arenicola (three specimens at KSC, MO, and US), whereas for $A$. watsonii two isotypes were traced at US. A new synonymy, $A$. arenicola $=A$. myrianthus, is proposed, the latter name having nomenclatural priority to the former one. Based on preliminary taxonomic observations, two varieties are recognized under A. greggii, var. greggii and var. muelleri, which differ from each other on the ratio tepals/fruit (about $2 / 3$ in var. muelleri vs. about 1 in var. greggii).
\end{abstract}

Keywords. Acnida; Mexico; synonymy; typification; U.S.A.

Resumen. Iamonico, D. 2020. Estudio de nomenclatura del género Amaranthus (Amaranthaceae). 11. Especies dioicas de Amaranthus pertenecientes a la sección Saueranthus. Darwiniana, nueva serie 8(2): 567-575.

Se lleva a cabo un estudio nomenclatural sobre los nombres de las especies dioicas de Amaranthus, pertenecientes a la sección Saueranthus (subgénero Acnida). Todos los nombres estudiados están válidamente publicados pero necesitan aclaraciones nomenclaturales. Se designan lectotipos para $A$. greggii var. muelleri (NY). Se indica la existencia de holotipos para $A$. ambigens, $A$. annectens, A. arenicola, A. myrianthus y $A$. watsonii (depositados en US, BM, GH y US). Se localizan isotipos para $A$. ambigens (un espécimen en NY), A. myrianthus (cinco especímenes en GH, M, MO, RM y US) y $A$. arenicola (tres especímenes en KSC, MO y US), mientras que para $A$. watsonii fueron localizados dos isotipos en US. Se establece una nueva sinonimia: $A$. arenicola $=A$. myrianthus, proponiéndose que el segundo nombre tenga prioridad nomenclatural sobre el primero. Con base en observaciones taxonómicas preliminares, se reconocen dos variedades de $A$. greggii, var. greggii y var. muelleri, que difieren entre sí en la relación entre la longitud de los tépalos y del fruto (aproximadamente 2/3 en la var. muelleri vs. aproximadamente 1 en la var. greggii).

Palabras claves. Acnida; Estados Unidos de América; México; sinonimia; tipificación. 


\section{INTRODUCTION}

Amaranthus L. (Amaranthaceae Juss.) is a genus comprising 70-75 species, of which approximately half of them are native to the Americas (Costea et al., 2001; Iamonico, 2015). This genus is critical from the taxonomical point of view, due to its high phenotypic variability, which led to nomenclatural disorders and misapplication of names (Mosyakin \& Robertson, 1996; Costea et al., 2001; Bayón, 2015; Hernández-Ledesma et al., 2015; Iamonico, 2015; Das, 2016]. The more recently proposed classification was published by Mosyakin \& Robertson (1996) who recognized three subgenera based on morphological and chorological data [subgenus Acnida (L.) Aellen ex K.R. Robertson, subgenus Albersia (Kunth) Gren. \& Godr., and subgenus Amaranthus]. Subgenus Acnida is classified three sections according to Mosyakin \& Robertson (1996), i.e. sect. Acnida (L) Mosyakin \& K.R. Robertson, sect. Saueranthus Mosyakin \& K.R. Robertson, and sect. Acanthochiton (Torr.) Mosyakin \& K.R. Robertson, the latter two sections including taxa characterized by having flowers with five well developed tepals, whereas species of sect. Acnida have flowers without tepals or, when occurring, the tepals are up to 2 but often reduced in size. A recent molecular study by Waselkov et al. (2018) highlighted that the classification of Mosyakin \& Robertson (1996) does not match the groups as identified in the phylogenetic trees and that it does not appear to be natural. However, Waselkov et al. (2018) stated that further studies need to clarify the infrageneric classification in Amaranthus. In addition to the taxonomic issues, nomenclature of the genus is highly complicate especially including misinterpretations of the names which were applied during the centuries in different ways: from the use of different names for a same taxon [e.g., A. chlorostachys and $A$. patulus Bertol. were often treated as a separate species, but they actually refer to A. hybridus L. (Iamonico, 2016a), or the various names in the A. tricolor group which have to be synonymized (see Iamonico 2014a, 2020a)], to the use of a single name for a wrong taxon (e.g., the name
A. gracilis sensu auct. non Desfontaines which is to be referred to $A$. viridis L.) and the occurrence of ambiguous names [e.g., A. gangeticus L. (Iamonico, 2014b) or $A$. commutatus A. Kern (Iamonico, 2020b)].

As part of the ongoing nomenclatural research on all Amaranthus names (I clarified over than 200 names), I here present the eleventh contribution which concerns the dioecious Amaranthus taxa, belonging to sect. Saueranthus (sensu Mosyakin \& Robertson, 1996). Previous papers on the genus treated Linnean names (Iamonico, 2014a; 2014b), names linked to the Italian flora (Iamonico, 2016a), Amaranthus gracilis Desf. and related species (Iamonico, 2016b), Moquin-Tandon's names (Iamonico, 2016c), names linked to the Australian flora (Iamonico \& Palmer, 2020), Willdenow's names (Iamonico, 2020a), Amaranthus polygonoides L. s.1. (Iamonico, 2020c), Amaranthus commutatus A. Kern (Iamonico, 2020b), and Roxburgh's names (Iamonico, 2020d). The study of nomenclature, which can be defined as the system of scientific names for taxa and their ranks (species, genus, family, etc.) and the rules and conventions for the formation, treatment, and use of those names, is very important in taxonomy (especially for critical groups such as Amaranthus) since, through the designation of the types, nomenclature regulates how names are used to communicate taxonomic hypotheses. Nomenclature has been providing classification systems of biodiversity for centuries and has been continuing to accommodate new knowledge in botany (see Thomson et al., 2018).

\section{MATERIAL AND METHODS}

This work is based on analysis of relevant literature (including protologues), and examination of specimens (digital images) preserved in the herbaria BM, FER, FI, GH, HFLA, IS, M, MO, NECB, NY, P, PESA, RM, RO, and US (codes according to Thiers, 2020) and the personal herbaria (not listed in Index Herbariorum) of Dr. Carlo Argenti (Belluno, Veneto Region, N-Italy) and Dr. Andrea Truzzi (Mantova, Lombradia Region, N-Italy). 
Specimens for comparisons, which were useful for the identification of the original material of the names studied, were examined during the last 15 years as part of the taxonomic investigation of the genus Amaranthus (for a complete list of most of the Herbaria consulted see Iamonico, 2015: 4, 2016c: 81-82, 2020b: 2, and Iamonico \& Palmer, 2020: 169).

The Articles of the International Code of Nomenclature for algae, fungi, and plants cited throughout the text (e.g. "Art. 38.1") follow the current edition, i.e. the Shenzhen Code, hereafter abbreviated as ICN (Turland et al., 2018).

\section{NOTES ON TYPIFICATIONS}

\section{Amaranthus ambigens}

Standley (1917: 106) validly published Amaranthus ambigens providing a detailed description and the following statement: "Type collected near Fountaindale, Illinois, by $M$. S. Bebb (U. S. Nat. Herb. no. 48297)". Two specimens collected by M. S. Bebb in Illinois were found at US (barcode US00106229), and NY (barcode NY01043148). Both these specimens bear branches of two plants, one male and the other one female. Since the species is dioecious, despite the occurrence in the protologue of the word "Type" as well as the indication of the herbarium and the number of collections (Standley, 1917: 106), these specimens cannot be considered as holotype and isotype of the name Amaranthus ambigens (see Art. 9.1 of ICN and the considerations by McNeill, 2014) and a lectotypification is necessary according to the Art. 9.3 of ICN. I here designated the female individual of the US specimen (plant on the left of the sheet) as the lectotype of the name Amaranthus ambigens, whereas plant on the left of the sheet of NY01043148 (female individual) is the isolectotype.

Note that a printed label by D. Pratt, dated 2002, occurs near the right-corner of the US00106229 and reports different identifications of the female plant (which would correspond to Amaranthus ambigens according to the label data) and the male plant (which would correspond to A. tuberculatus according to the label data). However, I disagree. The male plant perfectly matches the Standley's original description concerning the staminate flowers (see the discussion below).

Concerning the identity of the Standley's name, note that it was often considered as a heterotypic synonym of Amaranthus tuberculatus (Moq.) Sauer (see e.g., Ferren, 2011; Assad et al., 2017; GBIF, 2019; The Plant List, 2010a; POWO, 2020a-onward), whereas in few cases it was accepted as a distinct species (see e.g., Mohlenbrock, 2001; 2014; Das, 2016). According to the protologue and study of the lectotype held at US (US00106229), A. ambigens displays pistillate flowers with five well developed tepals. As a consequence, it cannot be synonymized with $A$. tuberculatus, which is a species with flower with 1-2 reduced tepals (as displayed by all the members of Amaranthus subgen. Acnida sect. Acnida). On the basis of the classification proposed by Mosyakin \& Robertson (1996), A. ambigens would belong to Amaranthus subgen. Acnida sect. Saueranthus that includes taxa characterized in having pistillate flowers with five tepals. Given that the bracts of $A$. ambigens are not deltate and do not enfold the flowers, it cannot be considered as part of the sect. Acanthochiton (which includes the single species $A$. acanthochiton). Bracts at the lectotype of Standley's species are ovatelanceolate and $1 / 2$ times as long as the sepals, so it cannot be identified neither with $A$. palmeri S. Watson nor with A. watsonii Standl., both having bracts longer than the perianth. Fruit of US00106229 is indehiscent, 2-3 mm long and, therefore, it is not identifiable as $A$. arenicola I.M. Johnston which shows fruits dehiscent. All in all, A. ambigens resembles A. greggii $\mathrm{S}$. Watson. However, morphological differences between these two latter mentioned species occur concerning the ratio length tepals/bracts (about 2 in $A$. ambigens vs. $1.2-1.4$ in $A$. greggii) and the diameter of the seed (1-1.1 mm A. ambigens vs. 1.2-1.7 in A. greggii). Since the sexual characters have high taxonomic value in Amaranthus (see e.g., Sauer, 1955; 1967; Bojian et al., 2003; Mosyakin \& Robertson, 2003; Iamonico, 2015; Iamonico \& Das, 2014; Iamonico \& El Mokni, 2018), I here propose 
to consider A. ambigens as a separate species among the dioecious amaranths belonging to the sect. Saueranthus according to Mosyakin \& Robertson (1996). However, further taxonomic studies need to give a final decision about the taxonomic value of this taxon.

\section{Amaranthus annectens}

This species was validly described by Blake (1915: 103) through a detailed description, the provenance and the habitat, as well as by citing a specimen ("Yucatan: seashore, Celstum, May 12th 1868, A. Schott, 360 (type in Brit. Mus.)" [= British Museum, which Herbarium is currently coded as BM]"). A specimen bearing various parts of a single plant collected by H. W. Schott in May 12, 1865 in Yucatan and numbered with " 360 " is found at BM (barcode BM000993090). Given that Blake (1.c.) reported a complete reference to the specimen, including the collection number and the Herbarium, I here consider the BM specimen as the holotype of the name Amaranthus annectens.

According to the current concept in Amaranthus (see e.g., Mosyakin \& Robertson, 2003), the holotype of A. annectens is identifiable as $A$. greggii based on the following characters: plants dioecious, bracts ovate and shorter than the tepals, pistillate flowers with 5 tepals, fruits about $3 \mathrm{~mm}$ long and as long as the perianth. A. greggii has nomenclatural priority on $A$. annectens (1877 vs. 1915). Note that Sauer (1955: 42) reported $A$. annectens in the synonymy of $A$. greggii although no type was indicated.

\section{Amaranthus greggii var. greggii}

Sauer (1955: 42-43) proposed to lectotypified the name Amaranthus greggii on a specimen deposited at GH (barcode GH00036997). This typification can be considered as correct since Watson (1877: 274-275) did not reported in the protologue neither the Herbarium nor a sheet number. Note that, despite Watson (1877: 274275) indicated, in the protologue, 1848 as the year of collection whereas Sauer (1955: 43) reported "December 17, 1847", he referred to a hand overwritten date which was originally "1848-49" (printed). Note moreover that a Watson's annotation reports "Amaranthus
Greggii, n. sp. Wats.". Sauer (1955: 42-43) also indicated a MO collection ("also MO!"). I traced two specimens at MO (barcodes MO101651 and MO101652) bearing plants collected by J. Gregg at Rio Grande. MO101651 includes the same printed label with correction of the year as in GH00036997, while MO101652 has an original hadwritten label. Finally, there is also a specimen at US (barcode US00106246) which bears the terminal part of one plant and the following original label (left corner of the sheet): "PLANTS OF MEXICO | Amaranthus greggii S. Wats | Dr. J. Gregg \#2 | 1848-49". There is also, just below the plant and directly on the sheet, an original annotation by S. Watson, i.e. "Amaranthus Greggii, n. sp. Wats.".

All the above mentioned specimens (one at $\mathrm{GH}$, two at MO, one at US) can be considered as duplicates of a same gathering. As a consequence, being GH00036997 the lectotype (Sauer, 1955: 42-43), MO101651, MO101652, and US00106246 are isolectotypes.

\section{Amaranthus greggii var. muelleri}

This variety was validly published by Uline \& Bray (1894: 272) based on a collection by F. Mueller "near Vera Cruz in 1853". The author intended to describe forms of Amaranthus greggii with stems more branched, leaves longer and narrower, synflorescence simple, sepals spreading and shorter than the fruit, and larger seeds. I found a specimen lodged at NY (barcode NY00324456) which bears two pieces of two plants (same gathering) and the original label "Vera Cruz. | 1853. legit Müller | 1855". This NY specimen constitutes original material for the name Amaranthus greggii var. muelleri, it matches the protologue and the diagnosis, and it is here designated as the lectotype of Amaranthus greggii var. muelleri.

According to the current concept in Amaranthus (see e.g., Sauer, 1955; Mosyakin \& Robertson, 2003), most of the characters given as diagnostic by Uline \& Bray (1894: 272) for the var. muelleri (i.e. branchness, leaves, synflorescence, and sepals) can be considered as included in the variability of A. greggii. Concerning the ratio length tepals/fruit, it seems to separate the var. muelleri from the typical forms being $2 / 3$ according to the diagnosis 
provided by Uline \& Bray (1.c.) and by the examination of the lectotype NY00324456 (tepals about $2 \mathrm{~mm}$ long, fruit about $3 \mathrm{~mm}$ long). On the other hand, A. greggii s.s. displays ratio tepals/ fruit about 1 (see e.g., Mosyakin \& Robertson, 2003). I think that this difference could be considered to separate the Uline \& Bray's taxon at subspecies rank. However, further investigations are necessary to verify the real separation between the two taxa and I prefer to maintain the variety rank for the moment.

\section{Amaranthus myrianthus}

Standley (1914: 506-507) validly published the name Amaranthus myrianthus providing a detailed description and the reference to specimens ("Type in the U. S. National Herbarium, 463205, collected in the vicinity of La Barra, 8 kilometres east of Tampico, Tamaulipas, Mexico, at sea level, February 1-8, 1910, by Dr. Edward Palmer (266). Additional material of the same collection is mounted on sheet 463206"). According to the Art. 9.1 of ICN, these citations refer, respectively, to the holotype (US no. 463205) and isotype (US no. 463206). These specimens were coded as US00106252 and US00106253. Furthermore, I also traced other specimens at GH (barcode GH00037026), M (barcode M0241406), and MO (barcode MO101653), all bearing labels whose data match the protologue: these three specimens are also isotypes for the name A. myrianthus. All the above cited specimens (two at US, one at GH, $\mathrm{M}$, and MO) bear plants that morphologically match the Standley's description and correspond to the current concept of $A$. arenicola based on the following characters: plants dioecious, bracts ovate and shorter or equal than the tepals, pistillate flowers with 5 tepals, fruits about $2 \mathrm{~mm}$ long and shorter than the perianth (see e.g., Johnston, 1948; Sauer, 1955; Mosyakin \& Robertson, 2003).

All things above discussed, the name Amaranthus myrianthus is considered as a heterotypic synonym of $A$. arenicola. Since $A$. myrianthus has nomenclatural priority over $A$. arenicola (years of publications 1914 vs. 1948, respectively) the correct name to be used is the former. No works in which these two names are synonymized appear to be published, and my proposed synonymization is new. In fact, the Standley's name was sometimes listed as heterotypic synonym of $A$. greggii (see e.g., The Plant List, 2010b; POWO, 2020b-onward). Finally, Sauer (1972: 433-434) supposed the existence of hybrids between $A$. greggii and $A$. arenicola "including the types of $A$. myrianthus Standl., collected at the mouth of the Rio Panuco in 1910 (E. Palmer 266, 511, CAS, GH, K, MO, US, WIS)". Based on the discussion given above, I disagree with Sauer's hypothesis.

\section{Amaranthus watsonii}

In describing Amaranthus watsonii, Standley (1914: 505-506) provided a detailed description and the following citation: "Type in the U. S. National, 692084, collected in the vicinity of Guaymas, Sonora, Mexico, in 1887, by Dr. Edward Palmer (312)". I found one specimen at US (barcode US00106268) collected by E. Palmer in Guaymas in 1887 and numbered with "312" and marked with US Catalog No. 692084. All these data totally match the Standley's protologue and US00106268 is to be considered as the holotype of the name Amaranthus watsonii. Further two specimens (US01013502 and US01013512) are isotypes. Note that Sauer (1955: 38) stated “...A. Watsonii (syntypes: Edward Palmer 312, on sand spit near Guaymas, Sonora, October, 1887, $q$ US!, here designated as lectotype; ...". However, based on the abve discussion, a lectotypification is not necessary and the proposal by Sauer (1.c.) is not correct according to the Shenzen Code.

\section{SYNOPSIS OF NAMES}

Amaranthus ambigens Standl., N. Amer. Fl. 21(2): 106. 1917. TYPE: U.S.A., Illinois, Fountaindale, s.d., M. S. Bebb s.n. [lectotype US00106229! (plant on the left), here designated, image of the holotype available at http://sweetgum.nybg.org/science/vh/specimendetails/?irn=1187933; isolectotype NY01043148! (plant on the left), image available at http:// sweetgum.nybg.org/science/vh/specimendetails/?irn=1187933]. 
Amaranthus greggii S. Watson var. greggii, Proc. Amer. Acad. Arts 12: 274-275. 1877. TYPE: Mexico, Tamaulipas, Mouth of the Rio Grande, 1848-1849, J. Gregg s.n. (lectotype GH00036997! designated by Sauer 1955: 42-43; image of the lectotype available at https://s3.amazonaws.com/huhwebimages/ 308CA3DB8C2040B/type/full/36997.jpg); isolectotypes at MO101651 (http:// legacy.tropicos.org/Image/800), MO101652 (http://legacy.tropicos.org/Image/801), and US00106246 (https://collections.nmnh.si.edu/ search/botany/search.php?action=10\&height= 5096\&width $=4000 \&$ irn $=10109525$ ).

$=$ Amaranthus annectens S.F. Blake, J. Bot. 53: 103. 1915. TYPE: Mexico, Yucatan, 12.5.1865, H. W. Schott 360 (holotype BM000993090!, image of the holotype available at https:/data. nhm.ac.uk/object/c87706db-0a18-499b-9513b9238a6c1ff2/1587600000000).

\section{Amaranthus greggii S. Watson var. muelleri} Uline \& W.L. Bray, Bot. Gaz. 19(7): 272. 1894. TYPE: Mexico, Vera Cruz, 1853, F. Müller s.n. (lectotype NY00324456!, here designated; image of the lectotype available at http://sweetgum.nybg. org/science/vh/specimen-details/?irn=263293).

Amaranthus myrianthus Standl., Bull. Torrey Bot. Club 506-507. 1914. TYPE: Mexico, Tamaulipas, Vicinity of La Barra, Tamaulipas, $8 \mathrm{~km}$ east of Tampico, at sea level, 1-8.02.1910, E. Palmer 266 (holotype US00106252!, image of the holotype available at https:// collections.nmnh.si.edu/search/botany/search. php? action $=10 \&$ height $=640 \&$ width $=454 \&$ irn $=$ 10133786); isotypes: GH00037026! (https:// s 3 . a mazonaws.com/huhwebimages/ D2D7764EA2854E6/type/full/37026.jpg), MO0241406 (https://plants.jstor.org/stable/ 10.5555/al.ap.specimen.m0241406?searchUri= plantName $\% 3 \mathrm{D} \% 2522$ Amaranthus\%2Bgreggii $\% 2 \mathrm{Bvar} \% 2 \mathrm{Bmuelleri} \% 2522 \% 26$ syn $\%$ 3D1), MO101653! (http://legacy.tropicos.org/ Image/10248), RM0000394! (https://rmh.uwyo. edu/gmapviewerphp? Image $=$ RM0000394\& Show=1), US00106253! (https://collections. nmnh.si.edu/search/botany/search.php?action= 10\&height=640\&width=454\&irn=10133787).
= Amaranthus arenicola I.M. Johnston, J. Arnold Arbor. 29: 193. 1948, syn. nov. TYPE: U.S.A., Hamilton County, Kansas, Sand hills, 03.08.1895, A. S. Hitchcock 428A (holotype GH00036981!, image of the holotype available at https://s3.amazonaws.com/ huhwebimages/770B6741B3484AA/type/ full/36981.jpg); isotypes: KSC15256 (non vidi ${ }^{l}$ fide Sauer 1955: 39); MO247457! (http://legacy. tropicos.org/Image/674), US00106231! (https:// collections.nmnh.si.edu/search/botany/search. php? action $=10 \&$ height $=640 \&$ width $=$ 454\&irn=10133783).

Amaranthus watsonii Standl., Bull. Torrey Bot. Club 41(10): 505-506. 1914. TYPE: Mexico, Sonora, 1887, E. Palmer 312 (holotype US00106268!, image of the holotype available at https://collections.nmnh.si.edu/search/botany/ search.php?action $=10 \&$ height $=10319 \&$ width $=$ 7319\&irn=10052723); isotypes: US01013502 (https://collections.nmnh.si.edu/search/botany/ search.php? action $=10 \&$ height $=640 \&$ width=454\&irn=10140115) and US01013512 (https://collections.nmnh.si.edu/search/botany/ search.php? action $=10 \&$ height $=640 \&$ width=454\&irn=10140205).

\section{Selected specimens examined Amaranthus greggii}

MEXICO. Tamaulipas. Mouth of the Rio Grande, 1848-1849, Gregg s.n. (GH00036997); ibidem (MO101651); ibidem (MO101652); ibidem (US00106246); Vicinity of Tampico, 3-6.06.1910, Palmer 511 (US00888501). Campeche. Ciudad del Carmen, 10.04.1933, Mell 2015 (US03541462). Yucatán. 12.05.1865, Schott 360 (BM000993090); Progreso, 14.01.1938, Crockett 69 (US03541461); Progreso, 23.07.1938, Lundell \& Lundell 8061 (US03541467). U.S.A. Texas; Galveston, 05.09.1920, Fisher 303 (US03540538). Texas, Strand, Jefferson Co., 04.09.1924, Tharp 3131 (US03540536).

${ }^{1}$ See the online database of the Herbarium KSC: http://www.konza.ksu.edu:8080/SearchVascular/ detail.jsp?record $=15256.0 \&$ column $=0 \&$ styleDir $=$ style 


\section{Amaranthus myrianthus}

MEXICO. Tamaulipas. Vicinity of La Barra, Tamaulipas, $8 \mathrm{~km}$ east of Tampico, at sea level, 1-8.02.1910, Palmer 266 (US00106252); ibidem (GH00037026); ibidem (MO0241406); ibidem (MO101653); ibidem (RM0000394); ibidem (US00106253). U.S.A. Kansas. Hamilton County, Sand hills, 03.08.1895, Hitchcock 428A (GH00036981); ibidem (MO247457); ibid em (US00106231). South Dakota; Sandhills, eastern Pennington Co., 15.07.1914, Over 2384 (US 03540040). Virginia. Dinwiddie County, Southeastern Virginia, Petersburg, 21.07.1939, Fernald \& Long 10633 (US 03540031). Kansas; Haviland, 09.1944, Rinkel s.n. (US03540035). Colorado. Baca County, Region of the Mesa de Maya. Along U.S. 160. 2 miles east of the Las Animas County line, 08.09.1948, Rogers 6435 (US03040125). Colorado. San Bernardino County, Coliseum Mine, Clark Mts., eastern Mohave Desert., 05.08.1950, Roos \& Roos 4905 (US03540124). Nebraska, Hall. Along Wood River about 1 mile south of Alda, 13.08.1962, Lemaire 2347 (US03540037).

\section{Amaranthus palmeri}

ITALY. Emilia-Romagna. Cervia, via Romea Nord (SS16), $2 \mathrm{~m}$ a.s.1, road embankment with ruderal vegetation, 08.10.2014, Faggi, Iamonico \& Ardenghi s.n. (HFLA! five sheets). Veneto. Among the localities Cesere, Zanon and Ferro, Camposampiero (PD) $\left(45^{\circ} 33^{\prime} 16.3^{\prime \prime} \mathrm{N}\right.$ 11'57'05.2”E), soybean field, 02.08.2018, leg. Milani, det. Milani \& Iamonico (FI); Verona Porta Vescovo (Verona), stazione ferroviaria (WGS84: 45.43572008N; 11.01641108E), decine di esemplari lungo i binari morti della stazione dei treni, 54 m, no esp., 17.10.2019, Bertolli (FI). Tunisia. Bizerta. North-Bizerta, Nadhour, 03-08 m a.s.l., 29.07.2015, El Mokni \& Iamonico s.n. (HFLA). USA. California. Banks of Rio Grande, July 1834, Berlandier 2407 (GH00037007); ibidem (MO247471, NY1043131); San Diego, Larkin station, 1875, Palmer 323 (GH00037006); ibidem (MO247470); ibidem (K000814911); Massachusetts. Malden, 04 Sep 1886, Collins s.n. (NEBC00735067); South Lawrence, 23.09.1902, Pease 510 (NEBC00735066). Los Angeles. N La Verne, light sunny soil in Citrus grove, 01.10.1932, Wheeler 1418 (P05159602).

\section{Amaranthus tuberculatus}

ITALY. Emilia-Romagna. Castel San Giovanni (Piacenza), sponda del Po, 1 October 1981, Soldano s.n. (HFLA!); Modena, quartiere Sacca, rudereti, Alessandrini s.n. (HFLA!); golena del Po tra ponte lagoscuro e Ravalle (Ferrara), 16 August 2006, Pellizzari 3481 (FER!). Marche. Fossombrone, alveo del fiume Metauro, 2006, Gubellini \& Pinzi s.n. (PESA!); ibidem, 15.09.2020, Iamonico s.n. (HFLA); Falconara marittima (Ancona), località Fiumesino (WGS84: $\left.43.637329^{\circ} \mathrm{N} ; 13.369258\right)$, incolti adiacenti Via del Fiume, 5 m s.l.m., 15.11.2020, Iamonico, Noor Hussain, Hofmann (HFLA, IS, PESA). Lombardia. Castelnuovo nella riva sinistra del Po, spiazzone di sabbie asciutte, 5 September 1974, Cacciato s.n. (RO!); Mantova, Borgoforte, alveo asciutto del Po, 31 August 1993, Truzzi 83 (Herb. Truzzi!); ibidem, 15 September 2002, Truzzi 283 (Herb. Truzzi!). Toscana. Pistoia, Larciano, area del Padule di Fucecchio, loc. Le Morette, $15 \mathrm{~m}$ a.s.l., 10 August 2004, La Rosa s.n. (FI!). Veneto. Belluno, Lambioi di Belluno, incolti, individuo femminile, $340 \mathrm{~m}$ s.l.m., 8 September 2000, Argenti 9839/3 (Herb. Argenti!); ibidem, male individual (Herb. Argenti!).

\section{Amaranthus watsonii}

MEXICO. Baja California. San José del Cabo, Lower California, 27.09.1890, Brandegee 492 (US03541668); Lower California. From Santo Domingo to Matancita, 14-15.11.1905, Nelsom \& Goldman 7282 (US03541666); Lower California. Magdalena Island, 03.1917, Orcutt 32 (US03541681); Las Animas, ranch at river-fork near base of El Picacho Peak, Sierra de la Laguna, 12.10.1941, Hammerly 292 (US03541677); Distrito del Sur. Behind large sand dunes on Gulf side near east end of El Mogote, the established san dune peninsula extending into La Paz Bay, 13.04.1949, Carter2727 (US03541676). Sonora. Guaymas, 1887, Palmer 675 (US03541662); Hillsides near Guaymas bathing beach at Miramar, 28.02.1933, Wiggins 6357 (US03541664); Guaymas, 23.10.1939, Gentry 4686(US03541680). U.S.A. Arizona. San Bernardino Ranch, Mexican Boundary Line. The headquarters of the San Bernardino Ranch were in Cochise county, 22.08.1893, Mearns 2006 (US00888860). 


\section{AKNOWLEDGEMENTS}

Thanks are due to the anonymous reviewers for the comments and suggestions given which were useful to improve the text. Special thanks to Dr. C. Argenti (Belluno city, Veneto Region, N-Italy) and to Dr. A. Truzzi (Mantova city, Lombardia Region, N-Italy) for the permission to examine the specimens preserved in their personal herbaria.

\section{BIBLIOGRAPHY}

Assad, R.; Z. A. Reshi, S. Jan \& I. Rashid 2017. Biology of Amaranths. The Botanical Review 83(4): 382-436. DOI: http://dx.doi.org/10.1007/s12229-017-9194-1

Bayón, N. D. 2015. Revisión taxonómica de las especies monoicas de Amaranthus (Amaranthaceae): Amaranthus subg. Amaranthus y Amaranthus subg. Albersia. Annals of the Missouri Botanical Garden 101(2): 261-383.

Blake, S. F. 1915. Two new Mexican Amaranths. Journal of botany, British and foreign 53: 103-104.

Bojian, B.; S. E. Clemants \& T. Borsch 2003. Amaranthus L. In Wu Z. Y., P. H. Raven \& D. Y. Hong (eds.), Flora of China, vol. 5, pp. 415-429. Beijing and St. Louis; Science Press and Missouri Botanical Garden Press.

Costea, M.; A. Sanders \& G. Waines 2001. Preliminary results towards a revision of the Amaranthus hybridus complex (Amaranthaceae). Sida 19: 931-974.

Das, S. 2016. Amaranthus: A Promising Crop of Future. Singapore: Springer.

GBIF 2019. Amaranthus tuberculatus (Moq.) J.D. Sauer. GBIF Secretariat. GBIF Backbone Taxonomy. Checklist dataset. $<$ https://www.gbif.org/species/5384347> [Accessed June 2020].

Ferren, W. R. 2011. Flora of New Jersey. Accessed April 28, 2020 at: https://www.njflora.org/wp-content/uploads/2011/02/ Amaranthaceae.pdf

Hernández-Ledesma, P.; W. G. Berendsohn, T. Borsch, S. von Mering, H. Akhani, S. Arias, I. Castañeda-Noa, U. Eggli, R. Eriksson, H. Flores-Olvera, S. Fuentes-Bazán, G. Kadereit, C. Klak, N. Korotkova, R. Nyffeler, G. Ocampo, H. Ochoterena, B. Oxelman, R. K. Rabeler, A. Sanchez, B. O. Schlumpberger \& P. Uotila 2015. A taxonomic backbone for the global synthesis of species diversity in the angiosperm order Caryophyllales. Willdenowia 45: 281-383.

Iamonico, D. 2014a. Lectotypification of Linnaean names in the genus Amaranthus L. (Amaranthaceae). Taxon 63(1): 146150. DOI: http://dx.doi.org/10.12705/631.34
Iamonico, D. 2014b. Amaranthus gangeticus (Amaranthaceae), a name incertae sedis. Phytotaxa 162(5): 299-300. DOI: http://dx.doi.org/10.11646/phytotaxa.162.5.2.

Iamonico, D. 2015. Taxonomic revision of the genus Amaranthus (Amaranthaceae) in Italy. Phytotaxa 199(1): 1-84. DOI: http://dx.doi.org/10.11646/phytotaxa.199.1.1

Iamonico, D. 2016a. Nomenclature survey of the genus Amaranthus (Amaranthaceae). 3. Plant Biosystems 150(3): 519-531. DOI: http://dx.doi.org/10.1080/11263504.2014.98 7188.

Iamonico, D. 2016b. Nomenclature survey of the genus Amaranthus (Amaranthaceae). 4. Detailed questions arising around the name Amaranthus gracilis. Botanica Serbica 40(1): 61-68.

Iamonico, D. 2016c. Nomenclature survey of the genus Amaranthus (Amaranthaceae). 5. Moquin-Tandon's names. Phytotaxa 273(2): 81-114. DOI: http://dx.doi.org/10.11646/ phytotaxa.273.2.1

Iamonico, D. 2020a. A nomenclature survey of the genus Amaranthus (Amaranthaceae). 7. Willdenow's names. Willdenowia 50(1): 147-155. DOI: https://doi.org/10.3372/ wi.50.50114

Iamonico, D. 2020b. A nomenclatural survey of the genus Amaranthus (Amaranthaceae) 10: What is Amaranhus commutatus? Thaiszia 30(2): 187-196. DOI: https://doi. org/10.33542/TJB2020-2-03

Iamonico, D. 2020c. Nomenclature survey of the genus Amaranthus (Amaranthaceae s.s.). 8. About Amaranthus polygonoides s.l. and A. anderssonii, two related taxa described from the tropical regions of America with notes on their taxonomy. Acta Botanica Mexicana 127: e1687. DOI: https://doi.org/10.21829/abm127.2020.1687

Iamonico, D. 2020d. A nomenclatural survey of the genus Amaranthus (Amaranthaceae) 9: names published by Roxburgh. Taiwania 65(4): 559-566. DOI: https://doi. org/10.6165/tai.2020.65.559

Iamonico, D. \& S. Das 2014. Amaranthus bengalense (Amaranthaceae) a new species from India, with taxonomical notes on A. blitum aggregate. Phytotaxa 181(5): 293-300. DOI: http://dx.doi.org/10.11646/phytotaxa.181.5.4

Iamonico, D. \& R. El Mokni 2018. Amaranthus tunetanus (Amaranthaceae), a new species from Tunisia and a diagnostic key to the North African taxa in subgen. Albersia. South African Journal of Botany 114: 78-83. DOI: https:// doi.org/10.1016/j.sajb.2017.10.011

Iamonico, D. \& J. Palmer 2020. Nomenclature survey of the genus Amaranthus (Amaranthaceae). 6. Names linked to the Australian flora. Australian Systematic Botany 33: 169-173. DOI: https://doi.org/10.1071/SB18062 
Johnston, I. M. 1948. Noteworthy species from Mexico and adjacent United Stase, II. Journal of the Arnold Arboretum 29: 193-197.

McNeill, J. 2014. Holotype specimens and type citations: General issues. Taxon 63(5): 1112-1113.

Mohlenbrock, R. H. 2001. Flowering Plants: Pokeweeds, Four-o'clocks, Carpetweeds, Cacti, Purslanes, Goosefoots, Pigweeds, and Pinks. Urbana: Southern Illinois University Press.

Mohlenbrock, R. H. 2014. Vascular Flora of Illinois: A Field Guide, Fourth Edition. Urbana: Southern Illinois University Press.

Mosyakin, S. L. \& K. R. Robertson 1996. New infrageneric taxa and combinations in Amaranthus (Amaranthaceae). Annales Botanici Fennici 33: 275-281.

Mosyakin, S. L. \& K. R. Robertson 2003. Amaranthus L. In Flora of North America Editorial Committee (eds.), Flora of North America North of Mexico (Magnoliophyta: Caryophyllidae, part 1., vol. 4, pp. 410-435. Oxford: Oxford University Press.

POWO 2020a-onward. Plants of the World Online. Amaranthus ambigens Standl. Facilitated by the Royal Botanic Gardens, Kew. $\quad<$ http://powo.science.kew.org/taxon/10601-2> [Accessed June 2020].

POWO 2020b-onward. Plants of the World Online. Amaranthus myrianthus Standl. Facilitated by the Royal Botanic Gardens, Kew. <http://www.plantsoftheworldonline.org> [Accessed June 2020].

Sauer, J. D. 1955. Revision of the dioecious amaranths. Madroño 13(1): 5-46.

Sauer, J. D. 1967. The Grain Amaranths and Their Relatives: A Revised Taxonomic and Geographic Survey. Annals of the Missouri Botanical Garden 54(2): 103-137.

Sauer, J. D. 1972. The dioecious amaranths: a new species name and major range extensions. Madroño 21: 426-434.

Standley, P. C. 1914. New or notable species of Amaranthus. Bulletin of the Torrey Botanical Club 41(10): 505-510.
Standley, P. C. 1917. North American Flora (Chenopodiales) Amaranthaceae, vol. 21(2). New York: The New York Botanical Garden.

The Plant List 2010a. The Plant List. A working list of plant species. Amaranthus ambigens Standl. <http://www. theplantlist.org/tpl1.1/record/kew-2632662> [Accessed June 2020].

The Plant List 2010b. The Plant List. A working list of plant species. Amaranthus myrianthus Standl. <http://www. theplantlist.org/tpl/record/kew-2632991> [Accessed June 2020].

Thiers, B. 2020 [continuously update]. Index Herbariorum: A global directory of public herbaria and associated staff. New York Botanical Garden's Virtual Herbarium. <http:// sweetgum.nybg.org/ih/> [Accessed June 2020].

Thomson, S. A. et al. 2018. Taxonomy based on science is necessary for global conservation. PLoS Biology 16(3): e2005075.

Turland, N. J.; J. H. Wiersema, F. R. Barrie, W. Greuter, D. L. Hawksworth, P. S. Herendeen, S. Knapp, W.-H. Kusber, D.Z. Li, K. Marhold, T. W. May, J. McNeill, A. M. Monro, J. Prado, M. J. Price \& G. F. Smith (eds.) 2018. International Code of Nomenclature for algae, fungi, and plants (Shenzhen Code) adopted by the Nineteenth International Botanical Congress, Shenzhen, China, July 2017. Regnum Vegetabile 159: 1-254.

Uline, E. B. \& W. L. Bray 1894. A preliminary synopsis of the North American species of Amaranthus. Botanical Gazzette 19: 313-320.

Waselkov, K. E.; A. S. Boleda \& K. M. Olsen 2018. A phylogeny of the genus Amaranthus (Amaranthaceae) based on several low-copy nuclear loci and chloroplast regions. Systematic Botany 43: 439-458.

Watson, S. 1877. Description of nine species of plants, with revision of certain genera. Proceedings of the American Academy of Arts and Sciences 12: 246-278. DOI: http:// dx.doi.org/10.2307/25138455 